\title{
Filling the Gap between Ecosystem Services Concept and River Basin Management Plans: The Case of Greece in WFD 20+
}

\author{
Ifigenia Kagalou * (i) and Dionissis Latinopoulos (1) \\ Department of Civil Engineering, Democritus University of Thrace, Xanthi 67100, Greece; dlatinop@civil.duth.gr \\ * Correspondence: ikagkalo@civil.duth.gr
}

Received: 7 August 2020; Accepted: 15 September 2020; Published: 18 September 2020

check for updates

\begin{abstract}
The ecosystem services (ES) concept is embedded in all new European directives but its integration in the Water Framework Directive (WFD) is absent, despite the latter being the major legislative tool. The research aims to assess the knowledge of ES that lies within the River Basin Management Plans (RBMPs) in Greece so as to further depict their representation in the relevant planning tools, to support policy making and express the implementation experience to Member States for assisting EU reloading processes. The information on the ES' status was extracted by the official RBMPs, processed and grouped following Common International Classification of Ecosystem Services (CICES) classification. The prioritization of ES included in the programs of measures (PoMs) further showed the targeting for each River Basin District (RBD). The results were not homogenous for the RBDs, revealing different needs in measures and indicating there is a lack in "communication" between the relevant EU and national regulations. Moreover, a wide suite of water-related ES is hindered in addressing multiple benefits coming from provisioning, regulating and cultural ES. For a proper WFD reload and continuation, the infusion of the ES concept and prerequisites in its objective, and the reviewing of the RBMPs' target and the suggestion of integrated PoMs are necessary steps that could deliver added value in such legislation.
\end{abstract}

Keywords: Greece; River Basin Districts; River Basin Management Plans; program of measures; ecosystem services; Water Framework Directive reload

\section{Introduction}

Human society is extremely dependent on aquatic ecosystems as part of the global water-energy-food [1,2]. Water-related ecosystems provide multiple benefits and services to society, making them essential for reaching several Sustainable Development Goals (SDGs) [3]. They offer significant economic, cultural, aesthetic, recreational and educational value while they help to sustain the global hydrological, carbon and nutrient cycles. They support water security and biodiversity, regulate flows and extreme conditions, purify water and replenish aquifers providing water for drinking, agriculture, energy generation, navigation, recreation and tourism. Their sustainability and their resilience depend upon social, economic and environmental strategies [4].

As a consequence of an increasing interest in the importance of key ecosystem services, including water-related ones, for maintaining human well-being, there is a lot of political and scientific drive to embrace the "ecosystem services based approach" [5-8]. It is important to highlight that the concept of ecosystem services (ES), although it was originally developed two decades ago, is still a relatively new concept, especially amongst water policy makers and managers. The 2012 Blueprint to Safeguard Europe's Waters [9] provided an overview of the state of ecosystems and their capacity to supply services, showing also that the ecosystem services approach can be useful at different stages of EU water 
policy implementation as the Water Framework Directive (WFD) [10]. Two years later, the resource document "Support Policy Development for Integration of Ecosystem Service Assessments into WFD and FD Implementation" reported by European Commission (EC) [11] provided inputs on how to use the ecosystem services approach to improve or support the implementation of the WFD and Floods Directive (FD) [12].

There are many links between the WFD principles and ES approach [13], while it is well documented that, among the Articles of the WFD related to ES, Article 11 (e.g., selecting cost-effective measures in the program of measures (PoMs)) is very important. Such importance lies in the fact that PoMs related to various management practices can provide important ES co-benefits. The River Basin Management Plans (RBMPs), with a temporal scope of six years, provide the basis for the protection and management of the environmental, social and economic value of water [14], while the chapter of PoMs is considered as the main instrument for establishing policy guidance by the competent authorities. For the waterbodies at risk of failing to achieve good ecological status, management responses should be in place for the improvement of the overall system's health by targeting the pressures and their drivers contributing to ecosystem dysfunction.

The suggested measures are classified in two main categories in terms of: (a) their compliance with the EU environmental and national legislative framework and further with environmental objectives, namely basic measures; and (b) site-specific measures for improvement of the ecological status along with awareness activities, namely supplementary measures. The development of River Basin Management Plans (RBMPs) could benefit from the concept of ES, prioritizing the measures through their PoMs and justifying the costs of protection and restoration for achieving a "good ecological status" [15]. The prioritization of the PoMs has been documented by several methodologies [16,17] providing the best option from a series of alternatives. Yet, there is a need to embed the ES concept addressing win-win solutions for multiple actors/stakeholders. Although references to ES as well as the terminology of ES were generally absent in the first cycle of the RBMPs, they have started to appear in the second cycle [13,15]). The Fitness Check of EU Freshwater Policy [18] and the Blueprint document [9] already acknowledged the importance of actions for protecting ecosystems and delivering services in the context of sustainable water management. These documents further highlight the need to integrate more of the ES in RBMPs, while Bouwma et al. [6] strongly suggested that for the WFD, a start might be to develop a guidance document on how in the next planning cycle of the River Basin Management Plans ecosystem services could be considered.

For such prioritization and for proper integration, given that the ES concept is correlated with people's well-being and prosperity, the PoMs should generally be connected with the affected areas and their inhabitants (end-users), keeping always as a primary goal the environmental values embedded in the WFD. Since the consensuses takes place once every 10 or more years, new applications that represent geospatially the real population per area have been produced by large international organizations (POPGRIDS). Examples of such are LandScan, WorldPop and World Population Estimate (WPE). Gridded population data can provide surveyors with updated estimates, and the grid cells in some products may be closer to the actual unit areas that are to be surveyed [19], assisting sustainable management and development.

In Greece, the 14 River Basins Districts (RBDs) (Table 1, Figure 1) were designated in 2010 by the Decision of the National Water Committee [20], while a national monitoring network according to the provisions of Article 8 of the WFD was established in 2011 [21] and turned operational in the following two years. As Greece lagged in the development of WFD compliant methods for the ecological classification of all waterbodies' types, significant effort was put in place to fill the gap resulting from the EC Decision in 2018 [22]). The first cycle of the RBMPs (2009-2015) of the 14 RBDs of the country was drawn up by the Special Water Secretariat, and the second cycle was published in 2017 (http://wfdver.ypeka.gr/en/home-en/), following the development of the WFD compliant methodologies and an extensive consultation of the first revision of the RBMPs. Regarding Greece, Kanakoudis et al. [23] highlighted serious weak issues regarding the qualitative assessment of the 
RBMPs, which affect the prioritization of PoMs, while Spiliotis et al. [17] pointed out the need of a scientific framework for the setup of a suite of PoMs supporting the ES in each water district.

Table 1. List of the Greek River Basin Districts with additional information on their areas, and the existence of transboundary waterbodies within their borders.

\begin{tabular}{llcl}
\hline RBD & Name & Size $\mathbf{( k m}^{\mathbf{2}} \mathbf{)}$ & Countries Sharing \\
\hline EL01 & West Peloponnese & 7235 & - \\
EL02 & Northern Peloponnese & 7418 & - \\
EL03 & East Peloponnese & 8442 & - \\
EL04 & West Sterea Ellada & 10,432 & - \\
EL05 & Epirus & 10,007 & Albania \\
EL06 & Attica & 3139 & - \\
EL07 & East Sterea Ellada & 12,268 & - \\
EL08 & Thessaly & 13,150 & - \\
EL09 & West Macedonia & 15,218 & Albania, N. Macedonia \\
EL10 & Central Macedonia & 14,269 & Bulgaria, N. Macedonia \\
EL11 & East Macedonia & 7320 & Bulgaria, N. Macedonia \\
EL12 & Thrace & 11,242 & Bulgaria, Turkey \\
EL13 & Crete & 8300 & - \\
EL14 & Aegean Islands & 9118 & - \\
\hline
\end{tabular}

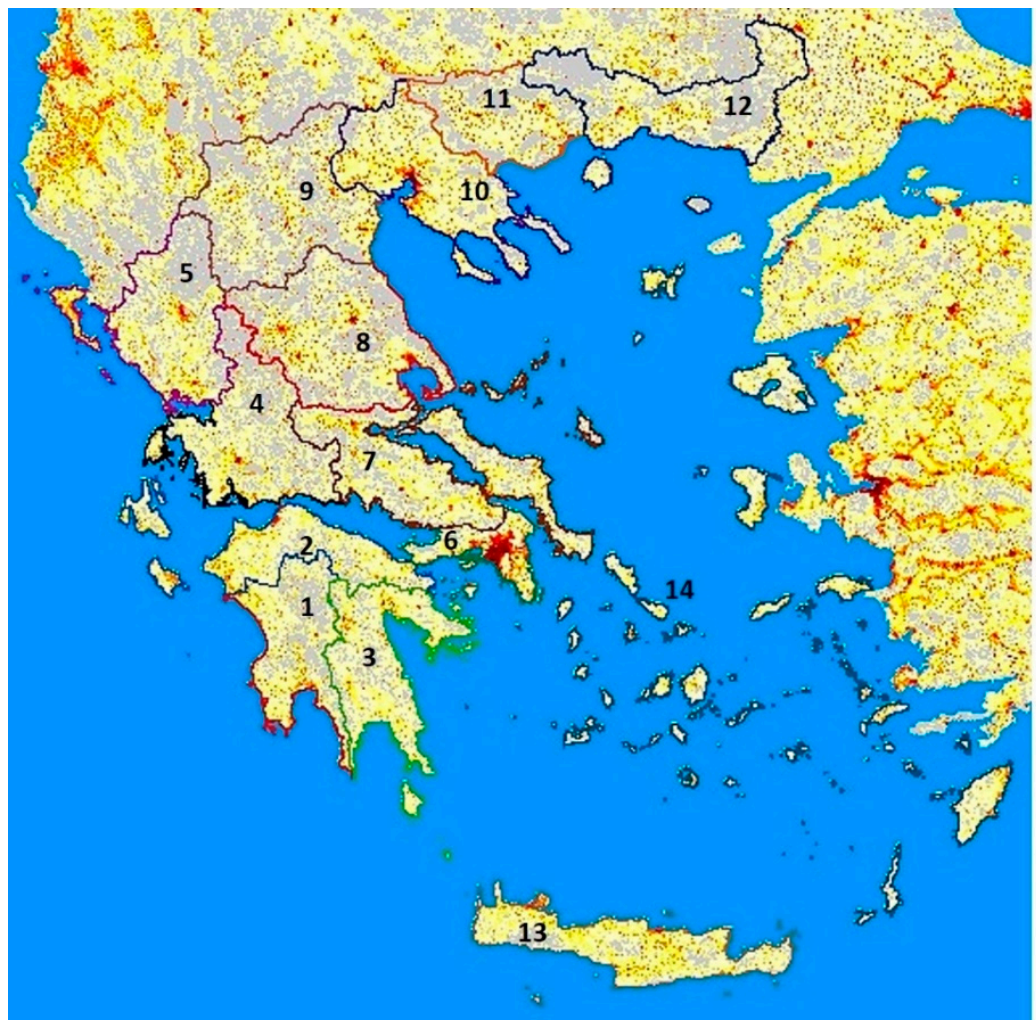

Greece breakdown in 14 River Basin Districts over LandScan PopGrid River Basin Districts 14 AEgEAN ISLANDS 6 ATाICA 10 C.MACEDONIA 13 CRETE 11 E.MACEDONIA 3 E.PELOPONNESE 7 E.ST.ELLADA 5 EPIRUS 2 NPELOPONNESE 8 THESSaLY 12 THRACE 9 W.MACEDONIA 1 W.PELOPONNESE 4 W.ST.ELLADA Population (inh.)

Figure 1. Location of Greek River Basin Districts under the Water Framework Directive.

The main aim of this study is to assess the current knowledge of ES status and related data along with the level of their embedment in the RBMPs design and application in Greece (Figure 1). Another aim is to orient future policy and practice on WFD implementation responding to two basic questions: (a) if and how the ES approach is met within the last Greek published RBMPs, and (b) has the ES concept been addressed through the program of measures? All RBMPS for all RBDs belonging in the Greek territory were processed for identification, extraction and quantification of ES to assess how the concept of ES is being represented in the relevant planning tools. Country-focused studies help 
national authorities and policy makers to identify potential gaps and to scientifically support the river basin management process which is referred to excellently by Kunz and Rittel [24] as an argumentative process. Taking into consideration that European water governance is characterized by processes of interplay and interaction [25], our paper provides the implementation experience of Member State (domestic) policy which is necessary for reloading processes at the EU level.

\section{Methodology and Database}

As a data source, we used the documents of the fourteen RBMPs (1st revision) corresponding to the fourteen RBDs in Greece, taking also into consideration the LandScan population maps. Additionally, documents produced for the reporting on directives and conventions, such as the Habitats Directive, the Birds Directive [26,27] and the Urban Wastewater Directive [28]), were also used as data sources. The identification and the classification of the ES was based on the CICES framework (CICES) [29]. We adopted the CICES framework since it is considered as a hierarchical one in structure, with each level providing a more detailed description of the identified ES [30,31]. The next step was to select the most suitable indicators associated with the WFD objectives. Some ES are relatively easy to quantify through indicators such as provisional services, while regulatory and maintenance and cultural ES are often more difficult to quantify. Thus, for each ES category, we selected indicators based on (a) the MAES analytical framework [32,33], (b) the resource document on Support Policy Development for Integration of Ecosystem Service Assessments into WFD and FD Implementation [11] and (c) the web dialogue of the working group of ESP (Ecosystem Services Partnership, https://www.es-partnership.org/community/ workings-groups/thematic-working-groups/twg-3-es-indicators/indicators-and-objectives/). With the intention that our work will truly support the decision makers, we also took into consideration the position paper by van Ouderhoven et al. [34] considering additional criteria for indicators selection. Evidently, data on freshwater abstraction for irrigation purposes and water uses for livestock activities, as well as other activities, such as industrial and hydropower, are considered the best available indicators for provisioning ES [35].

Furthermore, indicators expressing the ecological and chemical status of the waterbodies along with biodiversity aspects illustrate the maintenance of the nutrient cycles addressing the regulating ES. In the quantification of the regulating and maintenance ES, as WFD-related services, we assessed the "Maintenance of physical, chemical and biological conditions", applying as indicators (a) the chemical status of surface waters, (b) the ecological status of surface waters and (c) the chemical status of the groundwater. Yet, the pollution load in each RBMP is considered an anthropogenic pressure indicator expressing also the capability of the system for providing regulating services. Quantification of cultural services is even more difficult since we are referring to non-material spiritual, religious, inspirational and educational benefits and very often they are site-dependent. It is mostly related to recreation and tourism $[36,37]$ including components that have a specific link with people's behavior, e.g., degree of naturalness, protected areas as public recreation areas and water attractiveness [30,38]. Recently, the factor of remoteness and accessibility has been added in order to assess how the benefit (recreation) can be delivered to people. We applied the methodology of the Recreation Opportunity Spectrum (ROS) as the most suitable indicator for potential for recreation across Europe using the ROS zones [38]. The ROS system classifies all European Protected Areas under the network Natura 2000 in 9 classes (Table 2) using the Natura 2000 database (https://www.eea.europa.eu/data-and-maps/dashboards/natura-2000-barometer). Regarding the Greek Protected Areas, data were extracted from the national catalogues (depositories) [39] and further from the European databases (http://cdr.eionet.europa.eu/gr/eu/n2000/envwpjtvq/).

As second indicator of cultural ES, we applied the number of the Environmental Education Centers (EECs) established in each water district. Although recreation had been identified as the most common cultural ES, the environmental educational activities were also considered as a benefit and as a cultural "good" [40]. The Greek network of EECs provide a wide suite of formal and non-formal environmental education projects mostly to the school and student communities, and further to specific 
visitors' groups. Yet, they are considered as nuclei for the dissemination of environmental education leading to projects that are associated with multiple benefits for participating students [41].

Table 2. The Recreation Opportunity Spectrum classes (after Parracchini et al. [38]).

\begin{tabular}{cl}
\hline Class & Recreation Opportunity Spectrum \\
\hline 1 & Low provision-easily accessible \\
2 & Low provision-accessible \\
3 & Low provision-not easily accessible \\
4 & Medium provision-easily accessible \\
5 & Medium provision-accessible \\
6 & Medium provision-not easily accessible \\
7 & High provision-easily accessible \\
8 & High provision-accessible \\
9 & High provision-not easily accessible \\
\hline
\end{tabular}

\section{Results}

\subsection{Typology and Quantification of the ES in RBDs}

The identification and the quantification of the ES in the fourteen RBDs (namely EL 01 to EL 14) are presented in Table 3. Results for water consumption follow either the population load or the different productivity sectors in each RBD, depending on water availability (Figure 1, Table 3). It is apparent that freshwater abstractions for agricultural purposes are a major provisioning and more specifically nutritional ES. Agricultural water demand accounts from 66 to $2313 \mathrm{~m}^{3} 10^{6}$ year. RBDs such as Thessaly (EL 08), regions of Macedonia $($ EL 09, 10) and Thrace (EL 12) represent the agricultural "hot" areas due to the high water irrigation demand.

Livestock productivity as nutritional provisioning ES accounts from 0.4 to $10 \mathrm{~m}^{3} 10^{6}$ /year across the Greek RBDs. A significant proportion of water use goes to livestock consumption (drinking) and cleaning livestock housing in RBDs with a high number of farming activities such as the RBDs of Epirus (EL 05), Thessaly (EL 08) and Eastern Sterea Ellada (EL 07) (Table 3). Total water abstraction for drinking purposes and generally for use by the public sector has been also quantified as an indicator of nutritional (provisional) ES. Populated RBDs (such as Attica-EL 06, Figure 1) and water-deficient RBDs (such as Thessaly_EL 08 and Aegean Islands-EL 14) are already the largest water users nationally, either due to agriculture or tourism.

Two indicators were used to estimate the water-related provisional ES regarding the divisions of material and energy. Across the 14 RBDs, the water quantity allocated for the main industrial sectors, such as mining and fibers, contributes to the increase in this service in EL 06, EL 07 and EL 10 (Table 3). Hydropower is considered among the energy-related provisioning services with the vast majority being small (less than $10 \mathrm{MW}$ ) and concentrated in mountainous RBDs such as EL 04 (Acheloos Basin) and EL 05 (Arachthos Basin).

Indicators of chemical status reflect the chemical quality of both surface and groundwater waterbodies, while the ecological status expresses the quality of the structure and functioning of the surface waterbodies. Waterbodies with an "unknown" chemical and ecological status were excluded from our study (Table 3). In terms of chemical status, a low percentage (ranging from $0.95 \%$ to $7.14 \%$ ) of all types of surface waterbodies across all RBDs were classified as "less than good", while in almost half of the RBDs (N. Peloponnese, E. Peloponnese, West Sterea Ellada, East Sterea Ellada, Crete, Aegean Islands), no waterbody has been classified as "less than good". Natural surface waterbodies across RBDs show that a range of $2.80 \%$ to $58.09 \%$ were classified in terms of their ecological status as "less than good". The Aegean Islands (EL 14) and Central Macedonia (EL10) present the lowest and the highest percentage, respectively (Table 3). Regarding the chemical status of groundwater presented in the fourteen RBDs, it is shown that the observed percentage of waterbodies with a "not good" chemical status varies across RBDs ranging from $3 \%$ (EL 04) to $26 \%$ (EL 03). 
Table 3. Ecosystem services indicators grouped by major categories, depicting the status in all Greek River Basin Districts (RBDs).

\begin{tabular}{|c|c|c|c|c|c|c|c|c|c|c|c|c|c|c|}
\hline & \multicolumn{5}{|c|}{ Provisioning } & \multicolumn{7}{|c|}{ Regulating and Maintenance } & \multirow{2}{*}{\multicolumn{2}{|c|}{$\begin{array}{c}\text { Cultural } \\
\text { Physical, Intellectual } \\
\text { Interactions with Aquatic } \\
\text { Environment }\end{array}$}} \\
\hline & \multirow{2}{*}{\multicolumn{2}{|c|}{ 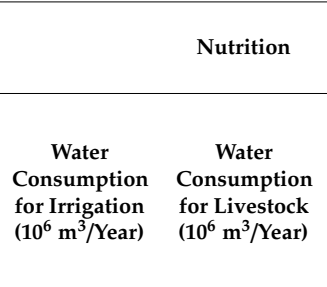 }} & \multirow[b]{2}{*}{$\begin{array}{c}\text { Water } \\
\text { Consumption } \\
\text { for Drinking } \\
\left(10^{6} \mathrm{~m}^{3} / \text { Year }\right)\end{array}$} & \multirow{2}{*}{$\begin{array}{c}\text { Materials } \\
\text { Water } \\
\text { Consumption } \\
\text { for Industry, } \\
\text { Mining, } \\
\text { Fibres etc. } \\
\left(10^{6} \mathrm{~m}^{3} / \text { Year) }\right.\end{array}$} & \multirow{2}{*}{$\begin{array}{c}\text { Energy } \\
\text { Water } \\
\text { Consumption } \\
\text { for } \\
\text { Hydropower } \\
\text { (MW. Max } \\
\text { Permission } \\
\text { Level) }\end{array}$} & \multicolumn{3}{|c|}{$\begin{array}{l}\text { Maintenance of Physical, Chemical and } \\
\text { Biological Conditions * }\end{array}$} & \multirow{2}{*}{$\begin{array}{c}\text { Biodiversity } \\
\text { Water } \\
\text { Related } \\
\text { Protected } \\
\text { Areas (No of } \\
\text { SPA, SCIs } \\
\text { or/and SACs) }\end{array}$} & \multicolumn{3}{|c|}{$\begin{array}{c}\text { Pollution Load } \\
\text { (Point and Non-Point Sources) }\end{array}$} & & \\
\hline & & & & & & $\begin{array}{l}\text { Chemical Status } \\
\text { of Surface Water } \\
\text { Bodies (\% in } \\
\text { Less Than Good) }\end{array}$ & $\begin{array}{l}\text { Ecological } \\
\text { Status of } \\
\text { Surface } \\
\text { Water (\% in } \\
\text { Less Than } \\
\text { Good) }\end{array}$ & $\begin{array}{l}\text { Chemical } \\
\text { Status of } \\
\text { Groundwater } \\
\text { Water } \\
\text { Bodies (\% } \\
\text { in Not } \\
\text { Good) }\end{array}$ & & $\begin{array}{c}\text { Total } \\
\text { Annual } \\
\text { Load BOD } \\
\left(10^{3}\right. \\
\text { tn/Year })\end{array}$ & $\begin{array}{c}\text { Total } \\
\text { Annual } \\
\text { Load N (10 } \\
\text { tn } / \text { Year })\end{array}$ & $\begin{array}{c}\text { Total Annual } \\
\text { Load P (10 } \\
\text { tn/Year) }\end{array}$ & $\begin{array}{l}\text { Environmental } \\
\text { Educational } \\
\text { Centres ( } \mathbf{N}^{\mathbf{0}} \\
\text { of Centres) }\end{array}$ & $\begin{array}{c}\text { Recreation } \\
\text { Opportunity } \\
\text { Spectrum } \\
\text { (ROS) } \\
\text { Classes }\end{array}$ \\
\hline EL 01 & 171.1 & 1.5 & 27.5 & 18.8 & 14.12 & 2.41 & 26.6 & 7.4 & 32 & 13.9 & 2.1 & 0.35 & 2 & $2,4,8$ \\
\hline EL 02 & 406.4 & 3.2 & 61.8 & 8.7 & 27.8 & 0.0 & 39.2 & 15.4 & 7 & 9.8 & 3.9 & 0.31 & 3 & $1,4,7,8,9$ \\
\hline EL 03 & 282.4 & 4.3 & 31.4 & 7.6 & & 0.0 & 25.0 & 26.0 & 8 & 7.9 & 1.5 & 0.9 & 3 & $4,6,7$ \\
\hline EL 04 & 717.0 & 8.0 & 39.0 & 2.0 & 114.07 & 0.0 & 20.5 & 3.0 & 10 & 10.3 & 5 & 0.6 & 5 & $1,4,7,8$ \\
\hline EL 05 & 688.0 & 10.0 & 58.0 & 4.5 & 70.18 & 2.0 & 32.0 & 3.1 & 14 & 25.5 & 9.7 & 2.9 & 5 & $1,4,8,9$ \\
\hline EL 06 & 66.0 & 0.4 & 416.0 & 18.0 & & 2.1 & 38.2 & 23.8 & 7 & 2.1 & 1.2 & 0.46 & 4 & $1,4,7$ \\
\hline EL 07 & 839.0 & 10.5 & 76.0 & 29.12 & 12.53 & 0.0 & 43.7 & 12.2 & 22 & 3.5 & 4.1 & 1.2 & 4 & $1,4,7,8$ \\
\hline EL 08 & $2,313.0$ & 13.0 & 94.0 & 9.0 & 12.39 & 7.14 & 40.0 & 12.0 & 9 & 15.3 & 6.5 & 0.6 & 5 & $1,8,9$ \\
\hline EL 09 & 937.87 & 7.2 & 140.77 & 13.5 & 61 & 2.83 & 50.3 & 5.67 & 44 & 11.6 & 6 & 1.6 & 4 & $1,7,8,9$ \\
\hline EL $10 * *$ & 1067.63 & 8.0 & 230.0 & 24.0 & 3.46 & 0.95 & 58.09 & 13.5 & 26 & 17.6 & 10.1 & 2.3 & 7 & $1,4,7$ \\
\hline EL 11 & 772.0 & 2.5 & 58.9 & 4.1 & 61 & 3.89 & 37.0 & 6.6 & 4 & 9.5 & 4 & 0.36 & 2 & $1,4,7$ \\
\hline EL 12 & 941.4 & 3.9 & 60.5 & 14.1 & 3.9 & 5.32 & 23.1 & 22.0 & 15 & 19.2 & 9.1 & 1.5 & 4 & $1,4,8,9$ \\
\hline EL 13 & $\begin{array}{l}415.0 \\
\end{array}$ & 4.16 & 78.1 & 0.75 & & 0.0 & 21.6 & 9.89 & 105 & 34.3 & 22 & 5.3 & 5 & $\begin{array}{c}4,8,9 \\
4,8,7\end{array}$ \\
\hline EL 14 & 111.36 & 2.39 & 90.66 & 0.05 & & 0.0 & 2.8 & 24.1 & 89 & 32.1 & 15.8 & 3.3 & 3 & $4,7,8$ \\
\hline
\end{tabular}


Biodiversity is at the hard core of the ES concept, highlighting the state of an ecosystem and the benefits for human well-being. The Natura 2000 sites have been designated under the Birds Directive (Special Protection Areas-SPAs) and the Habitats Directive (Sites of Community Importance-SCIs, and Special Areas of Conservation-SACs). Since Natura 2000 water-related protected areas offer a degree of security against degradation in RBDs, their number in each RBD is provided as a biodiversity ES indicator. Crete (EL 13) and the Aegean Islands (EL 14) RBDs present a high number of water-dependent Natura 2000 sites, including the special island wetland sites (Table 3), reflecting the high non-monetary value of nature in those districts.

Pollution load and nutrients enrichment from both point and non-point pollution sources in river basins threaten essential water-related ES illustrating their sustainability resilience. Applying as proxies the annual total load of biochemical oxygen demand ( $\mathrm{BOD}_{5} \mathrm{in} \mathrm{tn} / \mathrm{year}$ ), the total annual nitrogen load (as TN tn/year) and the total annual phosphorous load (as TP tn/year), we provide an overview of their variation across the Greek RBDs (Table 3). As regards the $\mathrm{BOD}_{5}$ proxy, high organic loads are produced in EL 05, EL 13 and EL 14 (Epirus, Crete and Aegean Islands), mostly coming from livestock activities, oil mills and semi-urban settlements not served by wastewater treatment plants.

Higher nutrients loads are present also in Crete (EL 13) and the Aegean Islands (EL 14), contributing to the total pollution load. A lower nutrient contribution has been recorded in East Peloponnese (EL 03) and Attica (EL 06), supposing that the main pollution burden comes more from the industrial sector than from the agricultural or/and livestock activities. There is a paradox with higher nutrient loads in the islands and Epirus which comes in contradiction with the local livestock and agricultural water consumption.

Concerning the mapping of the cultural ES, there is a rather non-homogeneous distribution of the number of Environmental Education Centers (EECs) across the RBDs. An average value of four centers per RBD ranges up to seven (EL 10) and declines to two (EL 01, EL 11). Of course, the Greek scheme of environmental education is a geographically dispersed network according to the regional governance structure of the country and not to the water districts. So, it is evident that in cases such as the Aegean Island district (EL 14), the number of centers (3) is considered as inadequate to provide environmental education services to a widely remote area.

Regarding the ROS indicator, almost all classes (Tables 2 and 3) represented in the 14 RBDs offer high recreation services, with the mountainous and remote ones being characterized by higher classes 7,8 and 9 (high provision categories with variation in accessibility). It is worth noting that the Athos area (EL 10) has not been included, since citizens have limited access due to the special administrative framework with a religious "separate" governance. It could be stated though that the natural resources are almost intact.

\subsection{The Program of Measures (PoMs)}

Concerning our second hypothesis "if the ES concept has been addressed through the program of measures reported in the first revision of the RBMPs", Figure 2 provides an overview of the measures and the prioritization of the potential ES that are being supplied. We divided the measures in two categories, i.e., "Technical" and "Administrative", and we excluded from our research the "basic administrative" measures since they are repeated through all RBMPs as compliance measures to the EU water policy. As a general output, the suggested technical measures deal with fertilizer and pesticide application control and changes towards low-input farming. As for the quantitative measures, all PoMs include measures for water saving or efficiency increase for water usage in agriculture, highlighting the importance of this sector's consumption. It is clear that the "ecological perception" of the WFD is not reflected upon the measures, since the majority of them deal with water as a resource to be protected and not as a living environment. As for the spatial distribution of these measures, southern Greece has the fewest in almost all categories and especially Peloponnese lacks measures in four-five general categories, depending on each RBD (Figure 2). 


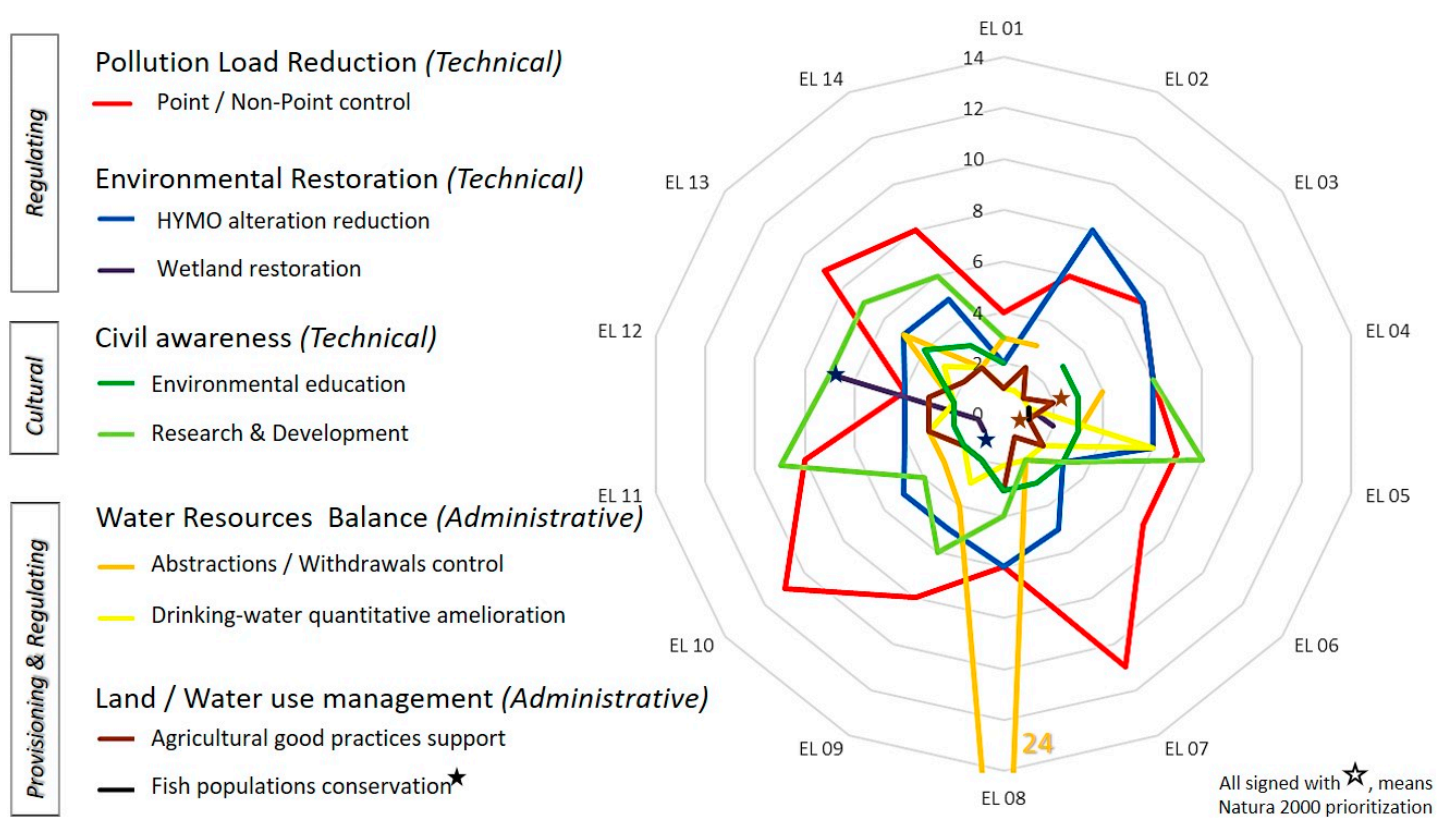

Figure 2. Program of measures breakdown per River Basin District, grouped per ecosystem services (ES) served and the nature of the measures.

Administrative PoMs mainly include measures for implementing existing relevant EU directives, measures related to increased knowledge for decision making and others related to environmental licensing and national environmental legislation, and these are coupled with measures regarding institutional changes, training/awareness raising and specific research and development projects.

Our results show that there is a lack in "communication" between the relevant EU and national regulations, thus the concept of ES becomes fuzzy. Only in two cases (West Sterea-EL 04 and Epirus-EL 05) is there a link between the WFD and the Habitats Directive addressing good agricultural practices and fish species conservation as regulating and provisioning ES. Regulating ES mostly tackling the point and non-point pollution sources are super expressed across RBDs, probably because the designation of PoMs is driven from the concept of "Pressures" in each river basin, rather than the ES concept. Yet, hydromorphological pressures are tackled through technical measures in all RBDs, responding to the pressures and impacts deriving from large-scale construction works (dams, water storages, hydropower establishments). On the contrary, restoration measures (habitat connectivity, fish ladders, inundation of floodplains, coastal erosion) that could provide all types of ES are very limited. As an example, Thessaly (EL 08) hosts a significant number (24) of PoMs on water resources balance (mainly water storage units) as a result of the high water needs of the entire region. The established PoMs across all Greek RBDs are expected to offer policy tools to water users and water authorities, but, looking from a different perspective, it can be seen that planning issues interdependent on water (land use, land cover changes, wetlands, biodiversity, climate crisis) have gained little attention.

Cultural ES are expressed as measures concerning educational and research and development projects. Among the suggested ones, across all RBDs, the farmers' awareness projects, as well as monitoring projects, are the most popular PoMs. We consider the farmers' awareness, and generally social learning, as something that could be an additional horizontal pillar in all PoMs due to its high importance to disseminate the value of water-related ES to the stakeholders' community.

\section{Discussion}

Since people benefit from various ES from river basins, ranging from nutrition and pollutants removal to cultural values, managing the costs and benefits becomes a complex [1,42]. This is the reason why the ES approach came into play, aiming at the organization of social challenges and natural science measurements $[43,44]$ towards catchments' sustainable management. The largest water-related 
policy that exists at this moment in Europe is the Water Framework Directive 2000/60/EC, introducing a "catchment-basin approach" in line with the Integrated Water Resources Management (IWRM) paradigm. Acknowledging that water in the European Union (EU) is under increasing pressure due to the continuous growth in demand for sufficient quantities of good quality, the WFD introduces a framework for the integrated basin approach in water management, considered as "the blueprint for IWRM". When applying the WFD, RBMPs have to be developed and reviewed on a six-year basis, specifying the actions required within each river basin to reach good ecological status. In cases where the ecological status is less than good, stakeholders have to apply strategy planning, meaning the PoMs, to manage anthropogenic pressures and improve ecosystem health. Yet, the practical implementation of best practices and experiences at the domestic level should be mobilized across Member States, along with governance organization levels which can act as an instrument for the delivery of the directive's benefits.

In the present paper, we tried to put the ES concept into practice, especially the ones embedded in RBMPs, so as to achieve the WFD objectives at the country level. To be clear with the terminology, the ES concept is not used in the national RBMPs, and no clear methodologies are provided. This was the case also in other European countries, such as Italy, England, Portugal, Romania and Belgium, where the term of ES was generally absent during the first cycle of RBMPs; the term appeared in the second one at an exploratory stage $[8,15]$. Now that the WFD is coming to its terminal stage 20 years later, integration with ES as an anthropocentric issue can be the basis for accomplishing SGG, 2030 Agenda and Green Deal goals since it can incorporate financial and economic measures, admeasure the added value of water uses and ensure stakeholder participation along with equity of end-users.

However, analyzing the Greek RBMPs, a wide suite of water-related ES is hindered in the effort to provide multiple provisioning, regulating and cultural ES. Agriculture continues to play a crucial role in the transformation and development of rural societies, while in arid and semi-arid EU Mediterranean countries, including Greece, irrigation for crop production is the larger consumer. Combined efforts between the new Common Agricultural Policy (CAP) and the WFD should be implemented to alleviate the pressures from irrigated farming. Kampas et al. [45], unraveling the synergies and conflicts in the most water-demanding Greek RBDs (EL 08), argued that there are opportunities for combining the efforts of the two policies in order to enhance water saving, taking also into consideration regional-specific factors. Since OECD [46] reported that Greece faces serious water challenges, in particular in terms of its agricultural water use, we strongly recommend co-operation between all stakeholders and policy makers in order to facilitate the design of PoMs clearly addressing ES such as the reassurance of the river's ecological flow, the ecological water level and the groundwater aquifer. Our results highlight that agriculture and population growth with all relevant services supporting the water-food-energy nexus are expected to be the key drivers for water demand in the coming decades.

Hydropower, along with other renewable energy sources, plays a key role in the implementation of the Renewable Energy Directive and in contributing to the EU energy targets for 2020-2030 and follows several requirements [22]. In Greece, the provisioning energy services originating from hydropower account for $28 \%$ of the total energy services [47]. Meanwhile, official EC documents endorse guidelines on hydropower development under the WFD [22,48], and there are not yet PoMs addressing the environmental requirements in relation to hydropower, ensuring the regulating ES, such as the protection of aquatic habitats' connectivity, sediment transport management, the remeandering of water courses, coastal erosion or the conservation of the composition and abundance of fish species. This is considered as an urgent issue since it also appeals for the need and commitment of halting and reversing the loss of aquatic biodiversity. The designers of the next cycle of PoMs have to face the challenge to strike the right balance among the EU relevant legislation including inter alia the Environmental Impact Assessment-EIA [49] and the Strategic Environmental Assessment-SEA Directives [50], the Birds and Habitats Directive [27] and the WFD [10] and Floods Directive [12]. 
Considering the water-related ES, the concept followed in the RBMPs is focused on "water uses" instead of services. This often drives the citizens' opinion towards more a "resource" perspective than an "ecosystem-based approach", thus synergistic actions that can be developed among uses as agriculture, energy and nature conservation, recreation and sustainability are not clear.

Regulating ES are not clearly referred to in the RBMP objectives, however many of the suggested PoMs show an indirect impact in specific ES contributing to meet the benefits from the WFD objectives (Articles 4 and 7). Pantsi and Kagalou [51], comparing the first planning cycle of RBMPs in Greece (Thessaly RBD) and Scotland (Solway Tweed), revealed differences in delivering the environmental goals, illustrating the economic and environmental benefits from the implementation of the WFD. Thus, a next cycle with a clear ES approach would be very promising. This remains the case even now, where not enough site-specific PoMs across the RBDs were found, not even in the "supplementary" class. Thus, a clear message should be drawn for the next Greek PoMs package, that they should address the maintenance of site-specific regulating ES. An example could be that apart from the reduction of pollution run-off, that is already clear, attention should be given to improving the water cycle at the regional level, mainstreaming practices that ensure soil-water interactions, facilitating measures for groundwater recharge, wetlands restoration measures and biodiversity conservation. Regarding the latter, although Borgström and Kistenkas [52] argued that EU water management and nature conservation laws should perhaps not be narrowed down to only some ecosystem services, but should definitely start from the aquatic or/and water-dependent Natura 2000 sites, as they are vulnerable and multi-functional ecosystems.

Urbanization trends in Greece in recent decades show a shift from the concentration in large metropolitan cities during the 1970s to a strengthening of medium-size urban centers in the late 1990s [53]. Urban waterbodies improve the quality of life in urban areas since they provide various ES [54,55]. In Greek RBMPs, and consequently in the relevant PoMs, the complete absence of measures addressing the urban aquatic ecosystems is apparent.

Administrative measures included in the Greek PoMs across all RBDs remain a weak issue towards achieving the goals of the WFD. While the Greek environmental policy is largely based on EU directives, the lack of implementation is the "Achilles heel" weakening the effectiveness of those foreseen in almost all RBDs. Since there is no requirement to monitor or map the ES, their links to specific PoMs are exacerbated by the gaps in implementation. We suggest that a stronger enforcement is required. For example, although the suggested regulations, in terms of administrative PoMs, the illegal water abstractions or discharges have not been tackled due to the lack of enforcement of the relevant regulations. One explanation is that management responsibilities rest with many authorities at central and local levels with consequent overlapping and coordination problems. Possible causes for inadequacies in PoMs implementation could also be the lack of knowledge on natural water systems behavior and their ES, financial limitations and the poor fitting with other relevant EU policies. Regarding the latter, the recent economic crisis reduced the perception of the severity of environmental issues [56] while creating mutual dependencies between responsible environmental policy implementing agencies that limited the generation of a comprehensive ES overview from complementary perspectives.

Unfortunately, there is not a path to include the cultural ES in EU and national assessments, while structural indicators of cultural services are described more often as the quality of natural areas as experienced by people, with accessibility being the most important indicator for cultural ES [44]. In our study, we included areas under the Natura 2000 network and their accessibility as an indicator for assessing the cultural ES across the Greek RBDs. Our results allowed the evaluation of the type of recreation that EU citizens could potentially have access to in the different Greek ROS zones.

We revealed that ROS zones across all RBDs offer high opportunity for nature tourism, obviously with benefits to the national, regional and local economy. Although it is beyond of the scope of the present study to distinguish which exact ES lead in socio-economic benefits, it is undoubtful that the demand of such services stimulates "green" employment [5,57-59]. Overall, PoMs do not include 
specific additional measures for water-related protected areas going beyond the strict WFD objectives, despite that engagement with other directives is highly recommended. Furthermore, this becomes even more urgent since the concept of SDGs goals $[3,60]$ has been put in place. Among the targets of Goal 6, Target 6.6 was set to "protect and restore water-related ecosystems, including mountains, forests, wetlands, rivers, aquifers and lakes by $2020^{\prime \prime}$. It seeks to halt the degradation and destruction of these ecosystems, and to assist the recovery of those already degraded, while the indicators used for Target 6.6 are coping with the water-related ES.

Public awareness on environmental issues is an educational process providing cultural/spiritual ES. Greece has created a robust form of environmental education through a decentralized scheme of EEC covering all RBDs, thus delivering, among others, educational services often as outdoor activities related to the aquatic systems. Regarding the suggested measures, although national and environmental NGOs' efforts have been made to raise water users' awareness, PoMs in each RBMP target the farmers' community and not a wider audience, resulting in a handicap for strong implementation across all stakeholders. PoMs should address collaborative water management fostering equity between users and minimizing socio-economic conflicts.

We further considered the research and development measures as a contribution to educational and knowledge development, hence contributing to the cultural benefits of the RBDs. The majority of the included in the PoMs refer to further monitoring protocols of specific waterbodies needing frequent surveillance or specific management.

\section{Conclusions}

This study focused on the linkages between the ES and the RBMPs of one EU Member State, but the findings may be relevant in the European context since they raise the issue of whether the ES could either be incorporated or even assist the implementation of the WFD for the years to come through a "reload" process.

In conclusion, linking the WFD objectives with ES prerequisites helps in reviewing the objectives of the RBMPs and the suggestion of PoMs that could deliver added value from the ES concept. The challenge for the next planning cycle is to produce fully operational PoMs, taking into consideration the already drafted national agenda about the ES assessment in Greece. Furthermore, the WFD clarifies that each suggested measure must not compromise other EU environmental legislation, otherwise it cannot be approved and go ahead. The concept of ES is more than necessary to be adopted in the RBMPs for the integration of different policies and stakeholders' views supporting also the socio-ecological system's interactions.

Author Contributions: Conceptualization, I.K.; methodology, I.K. and D.L.; software, D.L.; investigation, I.K. and D.L.; data curation, I.K. and D.L.; visualization, D.L.; writing-review and editing, I.K. and D.L. All authors have read and agreed to the published version of the manuscript.

Funding: This research received no external funding.

Conflicts of Interest: The authors declare no conflict of interest.

\section{References}

1. Kaval, P. Integrated catchment management and ecosystem services: A twenty-five year overview. Ecosyst. Serv. 2019, 37, 100912. [CrossRef]

2. Bennett, G.; Cassin, J.; Carroll, N. Natural infrastructure investment and implications for the nexus: A global overview. Ecosyst. Serv. 2016, 17, 293-297. [CrossRef]

3. WWAP (United Nations World Water Assessment Programme)/UN-Water. The United Nations World Water Development Report 2018: Nature-Based Solutions for Water; UNESCO: Paris, France, 2018. Available online: https://www.unwater.org/publications/world-water-development-report-2018/ (accessed on 16 June 2020).

4. Harmancioglu, N.B.; Barbaros, F; Cetinkaya, C.P. Sustainability issues in water management. Water Resour. Manag. 2013, 27, 1867-1891. [CrossRef] 
5. Dimopoulos, P.; Drakou, E.; Kokkoris, I.; Katsanevakis, S.; Kallimanis, A.; Tsiafouli, M.; Arends, J. The need for the implementation of an Ecosystem Services assessment in Greece: Drafting the national agenda. ONE Ecosyst. 2017, 2, e13714. [CrossRef]

6. Bouwma, I.; Schleyer, C.; Primmer, E.; Winkler, K.J.; Berry, P.; Young, J.; Vadineanu, A. Adoption of the ecosystem services concept in EU policies. Ecosyst. Serv. 2018, 29, 213-222. [CrossRef]

7. Grizzetti, B.; Lanzanova, D.; Liquete, C.; Reynaud, A.; Cardoso, A.C. Assessing water ecosystem services for water resource management. Environ. Sci. Policy 2016, 61, 194-203. [CrossRef]

8. Giakoumis, T.; Voulvoulis, N. Water Framework Directive programmes of measures: Lessons from the 1st planning cycle of a catchment in England. Sci. Total Environ. 2019, 668, 903-916. [CrossRef]

9. Communication from the Commission to the European Parliament, the Council, the European Economic and Social Committee and the Committee of the Regions A Blueprint to Safeguard Europe's Water Resources. Available online: https://eur-lex.europa.eu/legal-content/EN/TXT/?uri=CELEX:52012DC0673 (accessed on 7 June 2020).

10. EC-European Commission Water Framework Directive. Directive 2000/60/EC of the European Parliament and of the Council of 23 October 2000 establishing a framework for Community action in the field of water policy. Off. J. Eur. Communities 2000, 22, 2000.

11. Sørensen, M.M.; van Breugel, C.; Petersen, S.C.; Korsgaard, L.; Jensen, J.K.; Dannisøe, J.G.; Canavan, R.; COWI. Support Policy Development for Integration of Ecosystem Service Assessments into WFD and FD Implementation; Resource Document. 2014, p. 146. Available online: https://circabc.europa.eu/sd/a/95c931490093-473c-bc27-1a69cface404/Ecosystem\%20service_WFD_FD_Main\%20Report_Final.pdf (accessed on 20 May 2020).

12. CEC-Council of European Communities. Directive on the assessment and management of flood risks (2007/60/EC). Off. J. Eur. Communities 2007, 288, 27-34.

13. Vlachopoulou, M.; Coughlin, D.; Forrow, D.; Kirk, S.; Logan, P.; Voulvoulis, N. The potential of using the ecosystem approach in the implementation of the EU Water Framework Directive. Sci. Total Environ. 2014, 470, 684-694. [CrossRef]

14. Fidelis, T.; Rodrigues, C. The integration of land use and climate change risks in the Programmes of Measures of River Basin Plans-assessing the influence of the Water Framework Directive in Portugal. Environ. Sci. Policy 2019, 100, 158-171. [CrossRef]

15. Grizzetti, B.; Liquete, C.; Antunes, P.; Carvalho, L.; Geamănă, N.; Giucă, R.; Turkelboom, F. Ecosystem services for water policy: Insights across Europe. Environ. Sci. Policy 2016, 66, 179-190. [CrossRef]

16. Demetropoulou, L.; Lilli, M.A.; Petousi, I.; Nikolaou, T.; Fountoulakis, M.; Kritsotakis, M.; Nikolaidis, N.P. Innovative methodology for the prioritization of the Program of Measures for integrated water resources management of the Region of Crete, Greece. Sci. Total Environ. 2019, 672, 61-70. [CrossRef] [PubMed]

17. Spiliotis, M.; Panagiotou, L.; Kagalou, I.; Latinopoulos, D. A Fuzzified Multicriteria Outranking Method for Water Framework Directive Implementation in a Heavily Modified Urban Lake (Pamvotis, Greece). Water Resour. Manag. 2020, 1-20. [CrossRef]

18. European Commission. Commission Staff Working Document, The Fitness Check of EU Freshwater Policy, SWD (2012) 393 Final. Available online: https://ec.europa.eu/environment/water/blueprint/pdf/SWD-2012393.pdf (accessed on 14 May 2020).

19. Thomson, D.R.; Rhoda, D.A.; Tatem, A.J.; Castro, M.C. Gridded population survey sampling: A review of the field and strategic research agenda. Preprints 2020. [CrossRef]

20. Greek Parliament. Determination of the River Basins of the Country and Definition of the Responsible Regional Authorities for Their Management and Protection; FEK, 1383/B'/02-09-2010; Greek Parliament: Athens, Greece, 2010. (In Greek)

21. Greek Parliament. Defining the National Monitoring Network for Quality and Quantity of Water by Determining the Positions (Atations) of Measurements and the Management Bodies Obliged to Operate Them; Joint Ministerial Decision 140384/2011; Greek Parliament: Athens, Greece, 2011. (In Greek)

22. European Commission. Guidance on the Requirements for Hydropower in Relation to EU Nature Legislation; Publications Office of the European Union: Brussels, Belgium, 2018. Available online: https://ec.europa.eu/ environment/nature/natura2000/management/docs/Hydro\%20final\%20May\%202018.final.pdf (accessed on 21 June 2020). 
23. Kanakoudis, V.; Tsitsifli, S.; Azariadi, T. Overview of the river basin management plans developed in Greece under the context of the Water Framework Directive 2000/60/EC focusing on the economic analysis. Water Resour. Manag. 2015, 29, 3149-3174. [CrossRef]

24. Kunz, W.; Rittel, H.W.J. Studiengruppe fur Systemforschung, Heidelberg. Germany. Also Available Online from the Institute for Urban and Regional Development; Issues as Elements of Information Systems (Working Paper No. 131); University of California: Berkeley, CA, USA, 1970. Available online: http://iurd.berkeley.edu/sites/ default/files/wp/131.pdf (accessed on 13 July 2020).

25. Van Eerd, M.; Wiering, M.; Dieperink, C. Policy Discretion, Adaptation Pressure and Reloading Implementation Experiences in EU Water Governance: The Case of the Netherlands. Water Altern. 2019, 12, 886-906.

26. CEC - Council of the European Communities. Council Directive 79/409/EEC of 2 April 1979 on the conservation of wild birds. Off. J. Eur. Union 1979, L 103/1, 79.

27. EEC - Council of the European Communities. Council Directive 92/43/EEC of 21 May 1992 on the conservation of natural habitats and of wild fauna and flora. Off. J. Eur. Union 1992, 206, 7-50.

28. EEC-Council of the European Communities. Council Directive of 21. May 1991 concerning urban waste water treatment (91/271/EEC). Off. J. Eur. Union 1991, 34, 40.

29. Haines-Young, R.; Potschin-Young, M. Revision of the common international classification for ecosystem services (CICES V5. 1): A policy brief. ONE Ecosyst. 2018, 3, e27108. [CrossRef]

30. Maes, J.; Egoh, B.; Willemen, L.; Liquete, C.; Vihervaara, P.; Schägner, J.P.; Bouraoui, F. Mapping ecosystem services for policy support and decision making in the European Union. Ecosyst. Serv. 2012, 1, 31-39. [CrossRef]

31. Maes, J.; Liquete, C.; Teller, A.; Erhard, M.; Paracchini, M.L.; Barredo, J.I.; Meiner, A. An indicator framework for assessing ecosystem services in support of the EU Biodiversity Strategy to 2020. Ecosyst. Serv. 2016, 17, 14-23. [CrossRef]

32. Maes, J.; Teller, A.; Erhard, M.; Murphy, P.; Paracchini, M.L.; Barredo, J.I.; Lavalle, C. Mapping and Assessment of Ecosystems and Their Services: Indicators for Ecosystem Assessments under Action 5 of the EU Biodiversity Strategy to 2020; (European Union Technical Report; No. 2014-080); Publications Office of the European Union: Luxembourg, 2014. [CrossRef]

33. Kokkoris, I.P.; Mallinis, G.; Bekri, E.S.; Vlami, V.; Zogaris, S.; Chrysafis, I.; Dimopoulos, P. National Set of MAES Indicators in Greece: Ecosystem Services and Management Implications. Forests 2020, 11, 595. [CrossRef]

34. Van Oudenhoven, A.P.; Aukes, E.; Bontje, L.E.; Vikolainen, V.; Van Bodegom, P.M.; Slinger, J.H. 'Mind the Gap'between ecosystem services classification and strategic decision making. Ecosyst. Serv. 2018, 33, 77-88. [CrossRef]

35. Kokkoris, I.P.; Bekri, E.S.; Skuras, D.; Vlami, V.; Zogaris, S.; Maroulis, G.; Dimopoulos, P. Integrating MAES implementation into protected area management under climate change: A fine-scale application in Greece. Sci. Total Environ. 2019, 695, 133530. [CrossRef]

36. UNEP-WCMC. The World Database on Protected Areas (WDPA): January 2011; UNEP-WCMC: Cambridge, UK, 2011.

37. MA (Millennium Ecosystem Assessment). Ecosystems and Human Well-Being: Synthesis; Island Press/World Resources Institute: Washington, DC, USA, 2005. Available online: https://www.millenniumassessment.org/ documents/document.356.aspx.pdf (accessed on 15 June 2020).

38. Paracchini, M.L.; Zulian, G.; Kopperoinen, L.; Maes, J.; Schägner, J.P.; Termansen, M.; Bidoglio, G. Mapping cultural ecosystem services: A framework to assess the potential for outdoor recreation across the EU. Ecol. Indic. 2014, 45, 371-385. [CrossRef]

39. Greek Parliament. Revised National List of Natura 2000 Regions; Joint Ministerial Decision, 50743/2017; Greek Parliament: Athens, Greece, 2017. (In Greek)

40. Tratalos, J.A.; Haines-Young, R.; Potschin, M.; Fish, R.; Church, A. Cultural ecosystem services in the UK: Lessons on designing indicators to inform management and policy. Ecol. Indic. 2016, 61, 63-73. [CrossRef]

41. Yanniris, C. 20+ years of environmental education centers in Greece: Teachers' perceptions and future challenges. Appl. Environ. Educ. Commun. 2015, 14, 149-166. [CrossRef] 
42. De Groot, R.S.; Fisher, B.; Christie, M.; Aronson, J.; Braat, L.; Haines-Young, R.; Portela, R. Integrating the ecological and economic dimensions in biodiversity and ecosystem service valuation. In The Economics of Ecosystems and Biodiversity (TEEB): Ecological and Economic Foundations; Earthscan, Routledge: London, UK; Washington, DC, USA, 2010; pp. 9-40.

43. Braat, L.C.; De Groot, R. The ecosystem services agenda: Bridging the worlds of natural science and economics, conservation and development, and public and private policy. Ecosyst. Serv. 2012, 1, 4-15. [CrossRef]

44. Mononen, L.; Auvinen, A.P.; Ahokumpu, A.L.; Rönkä, M.; Aarras, N.; Tolvanen, H.; Vihervaara, P. National ecosystem service indicators: Measures of social-ecological sustainability. Ecol. Indic. 2016, 61, 27-37. [CrossRef]

45. Kampas, A.; Petsakos, A.; Rozakis, S. Price induced irrigation water saving: Unraveling conflicts and synergies between European agricultural and water policies for a Greek Water District. Agric. Syst. 2012, 113, 28-38. [CrossRef]

46. OECD. Environmental Performance Reviews: Greece 2019-2020 Review Process. 2019, p. 8. Available online: https://issuu.com/oecd.publishing/docs/epr-greece-review-process-brochure-_80f3bfef97b850 (accessed on 14 January 2020).

47. RAE-Regulatory Aythority for Energy 2017. National Report 2017: Regulation and performance of the Electricity Market and the Natural Gas Market in Greece. 2016, p. 153. Available online: http://www.rae.gr/site/file/system/docs/ActionReports/national_2017;jsessionid= c3fb776630daaa694898201b4cefb6f4a6e91472c8be.e3aPb3iLbxySe3yQch0SahuPay1ynknvrkLO1QzNp65In0 (accessed on 13 March 2019).

48. EC. Commission Staff Working Document. Report on the Implementation of the Water Framework Directive (2000/60/EC) and the Floods Directive (2007/60/EC)—Second River Basin Management Plans and First Flood Risk Management Plans. Report from the Commission to the European Parliament and the Council. COM (2019) 95 Final. 2019. Available online: http://ec.europa.eu/environment/water/water-framework/impl_ reports.htm (accessed on 27 February 2019).

49. Environmental Impact Assessment. Revised-Directive 2014/52/EU of the European Parliament and of the Council of 16 April 2014 amending Directive 2011/92/EU on the assessment of the effects of certain public and private projects on the environment. Off. J. Eur. Union 2014, 124, 1-18.

50. Strategic Environmental Assessment. Directive 2001/42/EC of the European Parliament and of the Council of 27 June 2001 on the assessment of the effects of certain plans and programmes on the environment. Off. J. Eur. Communities 2001, 197, 30-37.

51. Pantsi, C.; Kagalou, I. The Sustainability Issues of the River Basin Management Plans in South and North Europe and the European Water Framework Directive: Lessons Learned from Greece and Scotland. In Proceedings of the 12th International Conference on Protection and Restoration of the Environment, Skiathos, Greece, 29 June-3 July 2014.

52. Borgström, S.; Kistenkas, F.H. The Compatibility of the habitats directive with the Novel EU Green Infrastructure Policy. Eur. Energy Environ. Law Rev. 2014, 23, 36-44. Available online: https://edepot.wur.nl/ 352460 (accessed on 26 July 2020).

53. Salvati, L.; Sateriano, A.; Rontos, K. Towards an indicator of urban centrality? Exploring changes in present and resident population (1991-2011) in Greece. Ecol. Indic. 2016, 61, 188-192. [CrossRef]

54. Naselli-Flores, L.U.I.G.I. Urban Lakes: Ecosystems at Risk, Worthy of the Best Care. In Proceedings of the Taal2007: The 12th World Lake Conference, Jaipur, Rajasthan, India, 28 October-2 November 2008; Volume 1333, p. 1337.

55. McDougall, C.W.; Quilliam, R.S.; Hanley, N.; Oliver, D.M. Freshwater blue space and population health: An emerging research agenda. Sci. Total Environ. 2020, 140196. [CrossRef]

56. Calvário, R.; Velegrakis, G.; Kaika, M. The political ecology of austerity: An analysis of socio-environmental conflict under crisis in Greece. Capital. Nat. Soc. 2017, 28, 69-87. [CrossRef]

57. Latinopoulos, D. The impact of economic recession on outdoor recreation demand: An application of the travel cost method in Greece. J. Environ. Plan. Manag. 2014, 57, 254-272. [CrossRef]

58. Vlami, V.; Kokkoris, I.P.; Zogaris, S.; Cartalis, C.; Kehayias, G.; Dimopoulos, P. Cultural landscapes and attributes of "culturalness" in protected areas: An exploratory assessment in Greece. Sci. Total Environ. 2017, 595, 229-243. [CrossRef] 
59. Latinopoulos, D. The Role of Ecotourism in the Prespa National Park in Greece. Evidence from a Travel Cost Method and Hoteliers' Perceptions. J. Environ. Manag. Tour. 2020, 10, 1731-1741. [CrossRef]

60. UN Development Group. The Sustainable Development Goals Are Coming to Life: Stories of Country Implementation and UN Support. 2016. Available online: https://undg.org/wp-content/uploads/2016/12/ SDGs-are-Coming-to-Life-UNDG-1.pdf (accessed on 1 July 2020).

(C) 2020 by the authors. Licensee MDPI, Basel, Switzerland. This article is an open access article distributed under the terms and conditions of the Creative Commons Attribution (CC BY) license (http://creativecommons.org/licenses/by/4.0/). 